\title{
Pursuing the quest for better understanding the taxonomic distribution of the system of doubly uniparental inheritance of mtDNA
}

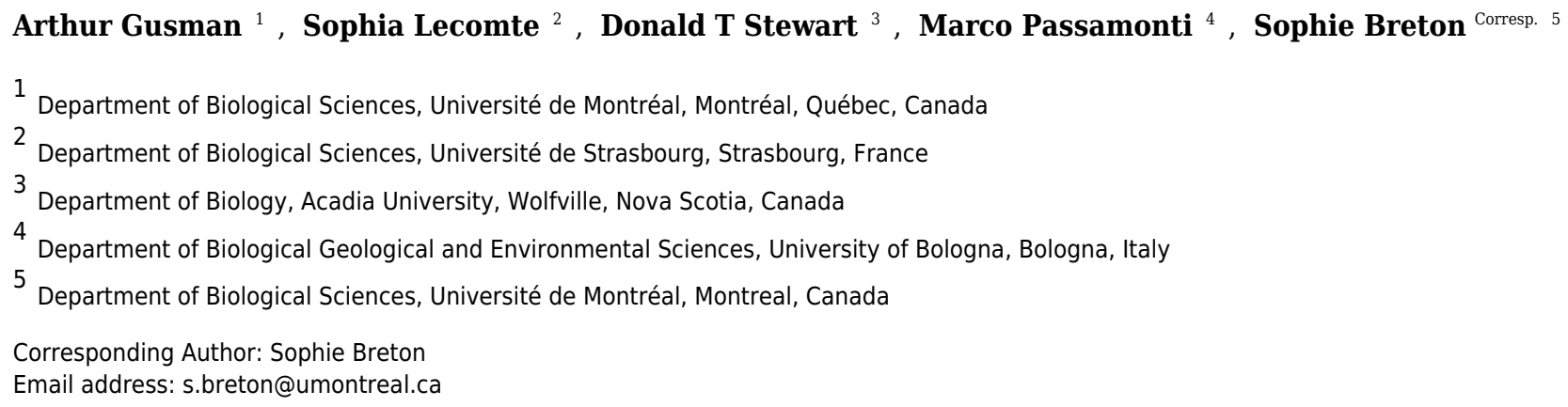

There is only one exception to strict maternal inheritance of mitochondrial DNA (mtDNA) in the animal kingdom: a system named doubly uniparental inheritance (DUI), which is found in several bivalve species. Why and how such a radically different system of mitochondrial transmission evolved in bivalve remains obscure. Obtaining a more complete taxonomic distribution of DUI in the Bivalvia may help to better understand its origin and function. In this study we provide evidence for the presence of sex-linked heteroplasmy (thus the possible presence of DUI) in two bivalve species, i.e. the nuculanoid Yoldia hyperborea (Gould, 1841) and the veneroid Scrobicularia plana (Da Costa, 1778), increasing the number of families in which DUI has been found by two. An update on the taxonomic distribution of DUI in the Bivalvia is also presented. 


\section{Pursuing the quest for better understanding the taxonomic distribution of the}

\section{2 system of doubly uniparental inheritance of mtDNA}

3

4 Short Title: Taxonomic distribution of DUI

5

6 This submission is intended as a research article

7

8

9

Arthur Gusman ${ }^{1}$, Sophia Lecomte ${ }^{2}$, Donald T. Stewart ${ }^{3}$, Marco Passamonti ${ }^{4}$, Sophie Breton ${ }^{1, *}$

11

12

13

14 23

${ }^{1}$ Department of Biological Sciences, Université de Montréal, Montréal, Qc, Canada H2V 2S9

${ }^{2}$ Department of Biological Sciences, Université de Strasbourg, Strasbourg, France

${ }^{3}$ Department of Biology, Acadia University, Wolfville, NS, Canada

${ }^{4}$ Dipartimento di Scienze Biologiche, Geologiche ed Ambientali, University of Bologna, Bologna, Italy

*Corresponding author: Sophie Breton, Email: s.breton@umontreal.ca 
30

31

32

33

34

42

43

44

\section{Abstract}

There is only one exception to strict maternal inheritance of mitochondrial DNA (mtDNA) in the animal kingdom: a system named doubly uniparental inheritance (DUI), which is found in several bivalve species. Why and how such a radically different system of mitochondrial transmission evolved in bivalve remains obscure. Obtaining a more complete taxonomic distribution of DUI in the Bivalvia may help to better understand its origin and function. In this study we provide evidence for the presence of sex-linked heteroplasmy (thus the possible presence of DUI) in two bivalve species, i.e. the nuculanoid Yoldia hyperborea (Gould, 1841) and the veneroid Scrobicularia plana (Da Costa, 1778), increasing the number of families in which DUI has been found by two. An update on the taxonomic distribution of DUI in the Bivalvia is also presented.

\section{Introduction}

Strict maternal inheritance (SMI) is considered to be the paradigm for mitochondrial DNA (mtDNA) transmission in animal species (Birky, 2001). One exception is found in bivalve molluscs, which possess a unique mode of mtDNA transmission named doubly uniparental inheritance (DUI) (Hoeh, Blakley \& Brown, 1991; Skibinski, Gallagher \& Beynon, 1994; Zouros et al., 1994a; Zouros et al., 1994b). DUI is characterized by the presence of two distinct sexassociated mitochondrial lineages: the female type (F mtDNA), which is transmitted through the eggs to all offspring, and the male type (M mtDNA) which is present in sperm, enters all eggs at the time of fertilization, but is only retained and transmitted through male offspring. In adults, the F-type mtDNA is predominant in all tissues of both sexes, except in the male gonad where the M-type mtDNA prevails; although some exceptions have been documented, adult females are 
55 essentially homoplasmic and adult males are heteroplasmic (reviewed in Breton et al., 2007;

56 Passamonti \& Ghiselli, 2009; Zouros, 2013). The stability of this system of heredity across

57 evolutionary time in several orders of bivalves has produced highly divergent $\mathrm{F}$ and $\mathrm{M}$ mtDNAs:

58 the mean nucleotide difference between both genomes is around $20 \%$ in many marine taxa 59 (orders Mytiloida and Veneroida) and can reach $>50 \%$ in freshwater mussels (order Unionoida)

60 (Breton et al., 2007; Doucet-beaupré et al., 2010). Although some major features of DUI are

61 quite well known - for example species with DUI show strong sex biases in offspring towards

62 one or the other sex following parental crosses (e.g., Kenchington et al., 2002; Kenchington et

63 al., 2009), both F and M lineages show rapid molecular evolution compared to other animals, the

$64 \mathrm{M}$ mtDNA usually evolves faster than the F mtDNA, M mitochondria show sex-specific

65 behavior in newly formed zygotes, and novel mtDNA-encoded protein-coding genes have been

66 found in species with DUI (Breton et al., 2007; Passamonti \& Ghiselli, 2009; Zouros, 2013;

67 Breton et al., 2014) - the main function of this peculiar system of mtDNA transmission still

68 remains undetermined. Sustained by the correlation between DUI and gonochorism (and the

69 absence of DUI and hermaphroditism), one main hypothesis suggests a link between this model

70 of heredity and the maintenance of separate sexes (Breton et al., 2011).

71 During the last decade, DUI has been described as a phenomenon that occurs in

72 approximately 40 bivalve species (e.g., Walker et al., 2006; Theologidis et al., 2008; Doucet-

73 Beaupré et al., 2010; Dégletagne, Abele \& Held, 2016). Considering the great deal of new

74 literature on DUI that has been done in the last few years, a more accurate count of species with

75 DUI is clearly needed. Moreover, with $\sim 25,000$ species (www.bivatol.org), DUI is likely very

76 widespread in the Bivalvia and it might be found in other molluscan groups as well (e.g.,

77 Parakatselaki, Saavedra \& Ladoukakis, 2015; Gusman et al., in press). A broad mitochondrial 
78 survey of bivalves and other mollusc species is crucial to gauge the prevalence of DUI across

79 molluscs and to evaluate its origin. To date, the vast majority of species with DUI that have been

80 reported belong to the freshwater bivalve order Unionoida (families Hyriidae, Margaritiferidae,

81 Unionidae) mostly because the PCR-based method used to detect DUI in this group, which is

82 based on amplifying the cox 2 extension specific to unionoid male mtDNAs (Curole \& Kocher,

83 2002), is simple and effective (Walker et al., 2006). The other groups in which species with DUI

84 have been found are the orders Mytiloida (family Mytilidae) (Hoeh, Blakley \& Brown, 1991;

85 Skibinski, Gallagher \& Beynon, 1994; Zouros et al., 1994a; Zouros et al., 1994b; Passamonti,

86 2007), Veneroida (families Arcticidae, Donacidae, Mactridae, Solenidae, Veneridae)

87 (Theologidis et al., 2008; Plazzi, 2015; Dégletagne, Abele \& Held, 2016), and Nuculanoida

88 (family Nuculanidae), an order belonging to the most basal protobranch bivalve lineage (Boyle \&

89 Etter, 2013). It is still unsettled whether DUI has a single origin followed by its loss in several

90 bivalve lineages or whether it has multiple and independent origins (Hoeh et al., 1996;

91 Theologidis et al., 2008; Zouros, 2013; Milani et al., 2014). To disentangle these two

92 possibilities, we must expand taxonomic sampling in a comprehensive manner.

93 The detection of DUI can be made by illustrating the presence of heteroplasmy in a male

94 individual, specifically by retrieving different mitochondrial haplotypes from the male gonad and

95 somatic tissues (the haplotype from male somatic tissues should be identical or more similar to

96 the haplotype observed in female gonad and somatic tissues) and/or by comparing male and

97 female gonad/gamete samples (male sequences should always cluster together and female

98 sequences too). Such an approach has already been successfully implemented in several previous

99 DUI studies (e.g., Passamonti \& Scali, 2001; Theologidis et al., 2008; Boyle \& Etter, 2013;

100 Plazzi, Cassano \& Passamonti, 2014; Plazzi, 2015; Vargas et al., 2015; Dégletagne, Abele \& 
101 Held, 2016). In the present study, we use this approach to test for the presence of DUI in two

102 bivalve species, i.e. the nuculanoid Yoldia hyperborea (Gould, 1841) and the veneroid

103 Scrobicularia plana (Da Costa, 1778), and we observe sex-linked heteroplasmy (thus the

104 possible presence of DUI) in both of them, increasing the number of families in which DUI has

105 been found by two. An update on the taxonomic distribution of DUI in the Bivalvia is also

106 presented.

107

108 Materials and Methods

109 Specimen's collection

110 Mature specimens of Yoldia hyperborea (Gould, 1841) were collected in the Baffin Sea

$111\left(76^{\circ} 20^{\prime} 50 \mathrm{~N}, 7^{\circ} 35^{\prime} 86 \mathrm{~W}\right)$ in August 2013. Scrobicularia plana (da Costa, 1778) samples were

112 directly sent from the French National Museum of National History to our laboratory. All

113 specimens were conserved in 95\% ethanol. To identify sex-biased heteroplasmy, each individual

114 was sexed by inspecting the gonads under a light microscope (100X) for the presence of eggs or

115 sperm, and only individuals unambiguously sexed were kept for the present study. Dissections

116 were carried on each individual to obtain somatic tissues (i.e., gills) and female or male gonad

117 for DNA extractions (see below). The number of specimens analyzed for both species include 7

118 males and 7 females.

119

120 DNA extraction, Polymerase Chain Reaction Amplification and Sequencing

121 Total genomic DNA was extracted separately from gonad tissue and from gill tissue with a

122 Qiagen DNeasy Blood \& Tissue Kit (QIAGEN Inc., Valencia, CA) using the animal tissue

123 protocol. The quality and quantity of DNA, respectively, were assessed by electrophoresis on 1\% 
124 agarose gels and with a BioDrop $\mu$ LITE spectrophotometer. Before PCR amplifications, all 125 samples were treated using OneStep ${ }^{\mathrm{TM}}$ PCR Inhibitor Removal Kit (Zymo Research, Irvine, CA)

126 according to the manufacturer's protocol. For both species, partial sequence amplification of

127 cytochrome oxidase subunit 1 (coxl) and large subunit ribosomal RNA ( $r r n L$ or $16 S)$ were

128 carried out in $50 \mu 1$ volumes comprising $5.0 \mu 1$ 10X Taq buffer, $1.0 \mu 1 \mathrm{dNTP} \operatorname{mix}(10 \mathrm{mM}), 2.0 \mu 1$

129 of each forward and reverse primer [10 $\mu \mathrm{M}$; LCO1490 and HCO2198 for coxl (Folmer et al., 130 1994), and 16Sar and 16Sbr for rrnL (Palumbi et al., 1991)], $0.25 \mu 1$ Taq DNA Polymerase

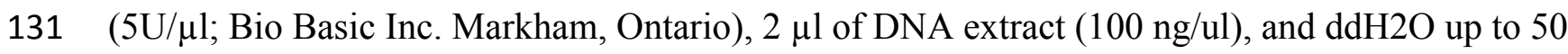

$132 \mu$ l. Reactions were performed on a TProfessional Basic Thermocycler with the following PCR 133 amplification conditions: initial denaturation at $95^{\circ} \mathrm{C}$ for $2 \mathrm{~min}$, followed by 35 cycles of $95^{\circ} \mathrm{C}$

134 for $20 \mathrm{sec}, 44^{\circ} \mathrm{C}$ for $40 \mathrm{sec}$ for coxl and temperature gradient $40-60^{\circ} \mathrm{C}$ for $40 \mathrm{sec}$ for $r r n L$, and $13572^{\circ} \mathrm{C}$ for $40 \mathrm{sec}$, followed by a final extension step at $72^{\circ} \mathrm{C}$ for $5 \mathrm{~min}$. The universal primers

136 16Sar and 16Sbr failed to amplify the $r r n L$ sequence in both S. plana and Y. hyperborea.

137 Resulting PCR products for coxl were visualized on 1\% agarose gels under UV light with SYBR 138 green dye (Life Technologies), and purified with the Qiagen QIAquick PCR Purification Kit 139 according to the manufacturer's protocol. The purified PCR products were sequenced at the 140 Genome Quebec Innovation Centre (McGill University), using the Applied Biosystem's 3730xl 141 DNA Analyzer technology.

143 DNA Cloning and Sequencing

144 Examination of chromatograms revealed the presence of multiple sequencing peaks only in male 145 gonad tissues of S. plana and Y. hyperborea, suggesting co-amplification of two different 146 mtDNA types. The amplified products of male gonads were thus cloned using the PGEM-T Easy 
147 vector (Promega, Madison, WI) to confirm the presence of F and M genomes. Ten recombinant

148 clones, for each species, were sent to the Genome Quebec Innovation Centre to be sequenced on

149 both strands using the primers pUC20 (5'-GTTTTCCCAGTCACGAC-3') and pUC2 (5'-

150 GAGCGGATAACAATTTCAC-3').

151

152 Sequence Analysis

153 Cox 1 sequences were edited and aligned using MEGA 6 (version6.06; Tamura et al., 2013).

154 Amino acid sequences were deduced using the invertebrate mitochondrial genetic code.

155 Calculations of nucleotide and amino acid $p$-distances were performed with MEGA 6 (with 1000

156 bootstrap replicates) (version6.06; Tamura et al., 2013).

157 Following a similar approach than Dégletagne et al. (2016) to look for the presence of

158 two intraspecific "F and M" clades in S. plana and Y. hyperborea, maximum likelihood (using

159 RAxML version 8.2.8; Stamakis, 2014) with bootstrap analyses (1,000 replicates) and Bayesian

160 phylogenies (using MrBayes v3.2.6; Huelsenbeck \& Ronquist, 2001; 2005; Ronquist et al.,

161 2012) were performed on coxl nucleotide sequences of both species with Soletellina virescens

162 (Bivalvia, Veneridae, Genbank accession number: JN859944) and Yoldia eightsii (Bivalvia,

163 Nuculanida, Genbank accession number: KJ571167) as outgroups for S. plana and $Y$.

164 hyperborea, respectively (i.e., closest sequences according to BLAST search). Bayesian

165 Information Criterion (BIC) (Schwartz, 1978) implemented in PartitionFinder (v1.1.1; Lanfear et

$166 a l ., 2012)$ was used to estimates the best-fitting models of evolution. Figtree (v1.4.2; Morariu et

$167 a l ., 2008)$ was used to edit the phylogenetic trees.

168 S. plana and Y hyperborea were included in an expanded phylogenetic analyses designed

169 to verify molecular relationships among DUI species in general. Maximum likelihood (ML), 
170 maximum parsimony (MP) and Bayesian phylogenies were thus performed on $\mathrm{F}$ and $\mathrm{M}$ cox 1

171 nucleotide and amino acid sequences from all DUI species known to date and Octopus vulgaris

172 (Mollusca: Octopoda) and Aplysia californica (Mollusca: Gastropoda) were used as outgroup

173 taxa. F and $\mathrm{M}$ coxl sequences other than those obtained in the present study for S. plana and $Y$.

174 hyperborea were retrieved from Genbank; the complete phylogenetic dataset is shown in Table

175 1. Coxl sequences were aligned using MEGA 6 (version6.06; Tamura et al., 2013) and the best-

176 fitting models of DNA evolution were selected using PartitionFinder (v1.1.1; Lanfear et al.,

177 2012) according to BIC values (Schwartz, 1978). Best models were applied whenever possible.

178 Data were partitioned according to nucleotide position and gaps were treated as missing data.

179 ML analyses were conducted with RAxML (version 8.2.8; Stamatakis, 2014). A non-

180 parametric bootstrap (Felsenstein, 1985) analysis was performed, using 1000 bootstrap replicates

181 and $20 \mathrm{ML}$ searches, to assess nodal support for both trees. Outgroups were set to be

182 paraphyletic to the monophyletic ingroup. MP analyses were carried out using PAUP software (v

183 4.0a147; Swofford, 2001). To optimize the chance of having the best topology, 100 random

184 stepwise additions under tree-bisection reconnection branch swapping were applied (Bogan \&

185 Hoeh, 2000). Reliability of the internal nodes was evaluated by 1,000 pseudoreplicates using the

186 heuristic search algorithm. Bayesian analyses were conducted using MrBayes (v3.2.6;

187 Huelsenbeck \& Ronquist, 2001; 2005; Ronquist et al., 2012). Each analysis consisted of two

188 independent runs of $4 \mathrm{MC}^{3}$ chains that were run for 10000000 generations. Convergence was

189 estimated through the log likelihood value of trees, potential scale reduction factor (PSRF) and

190 standard deviation of average split frequencies sampled every 1000 generations (Gelman \&

191 Rubin, 1992). Trees were sampled every 100 generations and a majority-rule consensus tree was

192 computed after discarding the first $25 \%$ as burn-in. Fidelity of the topology was evaluated with 
193 the posterior probabilities from the consensus tree. All phylogenetic trees were edited for easier

194 readability using FigTree (v1.4.2; Morariu et al., 2008).

195 All the alignments used for phylogenetic reconstruction are available here

196 (https://dx.doi.org/10.6084/m9.figshare.3798789.v1).

197

198 Results

199 Genetic distances

200 For this study, two new species were tested for the presence of DUI and 42 sequences were

201 examined in total: the number of sequences and haplotypes for each species are listed in Table 2.

202 Different haplotypes (i.e., for the same tissue among females or males, and thus non related to

203 DUI) were found for both species (Table 2). All mtDNA sequences are available via GenBank

204 under accession numbers KX44720-28. Sequences with the same haplotype were deposited only 205 once.

206 Intragroup (female sequences and male sequences, respectively) and intergroup (female

207 versus male sequences) nucleotide and amino acid $p$-distances are shown for both species in

208 Table 3. The $p$-distances between female and male sequences within each species are

209 significantly larger than the within group $p$-distances. Specifically, for Y. hyperborea cox 1

210 sequences, intragroup $p$-distances are low, i.e. 0.0014 for female sequences and zero for male

211 sequences (i.e., male sequences are identical), with standard error of \pm 0.0008 for female

212 sequences, whereas the between group $p$-distance is considerably higher with a value of 0.0596

$213 \pm 0.0079$ (amino acid $p$-distance is $0.0454 \pm 0.0124$ ). The same observation can be made for $S$.

214 plana cox 1 sequences: within group $p$-distances are $0.0067 \pm 0.0034$ and $0.0020 \pm 0.0014$, for 
215 female and male sequences, respectively, whereas the between group $p$-distance value is 0.0965

$216 \pm 0.0074$ (amino acid $p$-distance is $0.0659 \pm 0.0100$ ).

217

218 Phylogenetic analyses for Scrobicularia plana and Yoldia hyperborea

219 Phylogenetic analyses of partially sequenced $S$. plana cox 1 and $Y$. hyperborea coxl sequences

220 were conducted using the HKY + G model (Hasegawa et al., 1985). Based on high bootstraps

221 and posterior probability values, female and male haplotypes were clustered into two well-

222 supported clades for each species (Supplementary Figures S1 and S2).

223

224 Taxonomic distribution of DUI

225 Genetic distances and phylogenetic analyses provide evidence for sex-associated mitochondrial

226 heteroplasmy in Scrobicularia plana (Bivalvia: Semelidae) and Yoldia hyperborea (Bivalvia:

227 Yoldiidae), raising the total of bivalve families in which DUI has been discovered to 12 (Hoeh,

228 Stewart \& Guttman, 2002; Theologidis et al., 2008; Boyle \& Etter, 2013; Plazzi, 2015;

229 Dégletagne, Abele \& Held, 2016).

230 The list of the 103 bivalve species in which DUI has been found to date is presented in

231 Table 4. Evidence for DUI is reported in the literature for 96 species (and for 2 species in the

232 present study). For the other five species, the evidence is based on sequences derived from male

233 and female gonads and retrieved from GenBank (Okazaki, M., Shikatani, M., Nishida, M., \&

234 Ueshima, R., unpublished data). These sequences all show strong nucleotide divergence between

235 mitochondrial gene sequences obtained from male and female individuals, with $\mathrm{F}$ to $\mathrm{M}$ type $p$ -

236 distances ranging from $10 \%$ to $30 \%$.

237

238 Phylogenetic analyses 
239 A total of 608 cox 1 nucleotide sequences were aligned for a total of 114 operational taxonomic 240 units (OTUs) for phylogenetic analyses. GTR+I+G (Tavaré, 1980) was selected as the best-

241 fitting model of evolution for nucleotides (Table S1). The majority rule nucleotide-based BI tree

242 was favored as our best tree obtained for this study (Figures 1 to 4). It shows strong topology

243 similarity with both MP and ML trees (Supplementary Figures S3 and S4).

244 Main features of the BI tree (Fig. 1-4) are as follows: (1) pteriomorph (Mytiloida) +

245 Yoldia hyperborea $(\mathrm{PP}=0,80)$ and heterodont bivalves (Veneroida) $(\mathrm{PP}=0,99)$ are reciprocally

246 monophyletic with palaeoheterodont (Unionoida) bivalves being the sister group to these clades

$247(\mathrm{PP}=0,86) ;(2)$ the order Veneroida is well resolved with 3 nodes $(\mathrm{PP}=1.00)$ separating each

248 superfamily: Veneroidea, Tellinoidea and Mactroidea; (3) in both F and M clusters of the order

249 Unionoida, the superfamily Hyrioidea represented by H. menziesi is a positioned as a well

250 separated sister group ( $\mathrm{PP}=1.00)$ to the Unionoidea superfamily (Note: within the Unionoidea,

251 the separation between the two families Margaritiferidae and Unionidae is also apparent and well

252 supported only in the M cluster [PP =0.93]); (4) the F and M clades are reciprocally

253 monophyletic only in unionoids and Mytilus spp., i.e. the F sequences of different species cluster

254 together as do the $\mathrm{M}$ sequences, all the other species exhibit a phylogenetic pattern where $\mathrm{F}$ and

255 M sequences clusters are distinct from one another but are nonetheless sister groups; and (5)

256 branch lengths indicate a higher substitution rate for the $\mathrm{M}$ genomes relative to that of the $\mathrm{F}$

257 genomes for almost all species.

258

259

260 Discussion

261 Evidence for DUI in Scrobicularia plana and Yoldia hyperborea 
262 Both $p$-distance and phylogenetic analyses indicate the coexistence of sex-linked $\mathrm{F}$ and $\mathrm{M}$

263 mitochondrial lineages in S. plana and Y. hyperborea (Fig. 1-4; Table 3 and Supplementary

264 Figures S1 and S2). As mentioned earlier, the strategy of searching for sex-biased heteroplasmy

265 of mitochondrial gene sequences as a means for detecting DUI has been successfully employed

266 in other bivalve species (e.g., Boyle \& Etter, 2013; Vargas et al., 2015; Dégletagne, Abele \&

267 Held, 2016). DUI can also be detected by in vivo localization of male mitochondria in embryos:

268 an aggregate pattern of M-type mitochondria only into the male germline during early embryonic

269 stages is typical of DUI species (Cao, Kenchington \& Zouros, 2004; Obata \& Komaru, 2005;

270 Cogswell, Kenchington \& Zouros, 2006; Milani, Ghiselli \& Passamonti, 2012). The percentage

271 of nucleotide divergence between the $\mathrm{F}$ and $\mathrm{M} \operatorname{cox} 1$ sequences for both of these species, i.e.

$27233.4 \%$ for S. plana and $13 \%$ for Y. hyperborea, is within the range of what has been found for

273 other bivalves with DUI (e.g., 8\% in the veneroid Artica islandica [Dégletagne, Abele \& Held,

274 2016], 17\% in the nuculanoid Ledella sublevis [Boyle \& Etter, 2013]; 24\% in the mytiloid

275 Mytilus edulis [Breton et al., 2006], and 50\% in the unionoid Inversidens japanensis [Doucet-

276 Beaupré et al., 2010]).

277 The discovery of DUI in Y. hyperborea provides the first example of this unusual system

278 of mitochondrial DNA transmission in the family Yoldiidae, and the third case for the order

279 Nuculanoida (subclass Protobranchia; Boyle \& Etter, 2013). Protobranchia being the most basal

280 lineage within the Bivalvia (Giribet \& Wheeler, 2002; Smith et al., 2011), this result suggests

281 that the origin of DUI is older than the birth of the autolamellibranchiata (Theologidis et al.,

282 2008; Doucet-Beaupré et al., 2010; Boyle \& Etter, 2013). However, of the three protobranch

283 orders, only the Nuculanoida, has been reported to exhibit DUI (Boyle \& Etter, 2013), and the

284 phylogenetic status of this order is still being questioned. Indeed, recent phylogenetic studies 
285 suggest that the Nuculanoida is not a member of the basal protobranch group, which includes 286 Nuculoida and Solemyoida, but instead is associated with the Pteriomorpha (Wilson, Rouse \& 287 Giribet, 2010 [based on 3 nuclear and 2 mitochondrial genes]; Plazzi et al., 2011 [based on 4 288 mitochondrial genes]; Breton et al., unpublished [based on complete mitochondrial genomes and 2893 nuclear genes combined with an extensive morphological dataset]), whereas other recent 290 studies based on four nuclear genes (Sharma et al., 2012) and phylogenomic data (Smith et al., 291 2011; González et al., 2015) supported the monophyly of Nuculanoida + Opponobranchia 292 (Nuculoida and Solemyoida; Giribet, 2008). The presence of DUI in protobranchs thus remains 293 an open question until the publication of a well-supported and robust phylogeny of bivalves 294 showing the monophyly of the traditional clade Protobranchia (i.e., Solemyoida + Nuculoida + 295 Nuculanoida) and/or until the discovery of DUI in nuculoid or solemyoid bivalves. The peppery furrow shell Scrobicularia plana belongs to the order Veneroida. It is the

297 first reported species with DUI from the family Semelidae, raising the total number of veneroid 298 families in which DUI has been discovered to six (Theologidis et al., 2008; Plazzi, 2015;

299 Dégletagne, Abele \& Held, 2016; present study). Apart from providing new insights into the 300 taxonomic distribution of DUI, S. plana may play a key role for better understanding the 301 hypothesized role of DUI in sex determination (e.g., Breton et al., 2007; Breton et al., 2011a; 302 Breton et al., 2014; Breton \& Stewart, 2015; Mitchell et al., 2016). Indeed, an "intersex" 303 condition, i.e. the appearance of oocytes in male gonads following endocrine disruption, has 304 been reported in S. plana and is associated with differentially expressed mitochondrial transcripts 305 in males exhibiting intersex compared to "normal" males (Chesman \& Langston, 2006).

306 Specifically, using a suppressive subtractive hybridization approach, Ciocan et al. (2012) were 307 able to determine that several mitochondrial mRNA transcripts were down-regulated in clam 
308 intersex samples (i.e., cox1, cytb, nad1, nad2, nad3, nad4). Interestingly, we observed that the 309 down-regulated coxl sequence identified by Ciocan et al. (2012) was identical to the male coxl

310 sequences from our study, indicating that the down-regulation of male mitochondrial sequences

311 is associated with the appearance of female characteristics in male gonads in this species. These

312 results provide more evidence for a link between DUI and sex determination or differentiation. It

313 is noteworthy that the intersex has been shown to be a widespread phenomenon in bivalves,

314 including in species with DUI (e.g., R. philippinarum [Lee et al., 2010] and M. galloprovincialis

315 [Ortiz-Zarragoitia \& Cajaraville, 2010]).

316

317 Taxonomic distribution of DUI in bivalves: an update

318 Including the two species in the present study, DUI has been reported to date in 104 bivalve

319 species belonging to four subclasses (Heterodonta, Palaeoheterodonta, Pteriomorphia,

320 Protobranchia [but see above comments regarding the questionable inclusion of Nuculanoida

321 within the Protobranchia]), four orders (Mytiloida, Nuculanoida, Unionoida, Veneroida), nine

322 superfamilies (Arcticoidea, Hyrioidea, Mactroidea, Mytiloidea, Nuculanoidea, Solenoidea,

323 Tellinoidea, Unionoidea, Veneroidea) and twelve families (Arcticidae, Donacidae, Hyriidae,

324 Mactridae Margaritiferidae, Mytilidae, Nuculanidae, Semelidae, Solenidae, Unionidae

325 Veneridae, Yoldiidae) (Table 4 and Fig. 1-4). However, DUI is certainly more widespread in the

326 Bivalvia given that its detection remains difficult; the higher rate of molecular evolution of $\mathrm{M}$

327 type mitochondrial genomes may make it less likely that "universal" mitochondrial primers will

328 anneal to and amplify the M type (Theologidis et al., 2008; Zouros, 2013). In addition, the

329 process of mitochondrial genome "masculinization," i.e. when an F genome invades the male

330 route of transmission, can also make the paternally-transmitted genome almost indistinguishable 
331 from the maternally-transmitted one (Stewart et al., 2009; Theologidis et al., 2008; Zouros,

332 2013). Additional studies of bivalves and other mollusc species will significantly contribute to

333 better understanding the taxonomic distribution of the system of doubly uniparental inheritance

334 of mtDNA.

335

336 Phylogenetic analyses and the origin of DUI

337 As for other veneroid and nuculanoid species (e.g., Theologidis et al., 2008), the sex-linked

338 mtDNA sequences of S. plana and Y. hyperborean, respectively, exhibit a phylogenetic pattern

339 in which the $\mathrm{F}$ and $\mathrm{M}$ mtDNA sequences are different from one another but yet cluster together

340 in a monophyletic group (Fig. 1-4). Such a pattern can also be seen in the order Mytiloida (Fig.

341 1-4), except for the Mytilus species complex, which is in agreement with previous studies (e.g.,

342 Doucet-Beaupré et al., 2010). On the other hand, the observed F/M phylogeny of unionoids

343 contrasts with the patterns observed in the mytiloids, nuculanoids and veneroids. In unionoids,

344 all of the $\mathrm{F}$ sequences cluster together and all of the $\mathrm{M}$ genomes cluster together such that the $\mathrm{F}$

345 sequences form a monophyletic clade and the $\mathrm{M}$ sequences form a monophyletic clade. Similar

346 results have previously been obtained and have suggested that the $\mathrm{M}$ and $\mathrm{F}$ lineages in the order

347 Unionoida have been distinct and maintained for at least 200 million years (e.g., Doucet-Beaupré

348 et al., 2010). The observed phylogenetic pattern of the unionoids could be related to the absence

349 of a masculinization event in this group for over 200 million years (Hoeh et al., 2002). One

350 hypothesis explaining why F-to-M masculinization events do not occur in freshwater mussels

351 involves the cox2 extension present only in the M genome (Curole \& Kocher, 2002). If this

352 extension is essential for the function or transmission of the M genome (Curole \& Kocher, 2002;

353 Chakrabarti et al., 2006, 2007) then masculinization events are no longer possible in this group, 
354 unless $\mathrm{F}$ genomes are able to obtain, by recombination, those male-specific elements necessary

355 for being paternally transmitted (Stewart et al., 2009; Doucet-Beaupré et al., 2010). The M

356 genome is considered as a "nearly selfish" element in the sense that it does fulfill its function

357 only if this work cannot be done by the F genome. In other words, paternally-transmitted $\mathrm{mt}$

358 genomes only perform male specific functions. This restricted functionality of the M mtDNA to

359 male gonad tissue is one factor that may explain why the $\mathrm{M}$ genome usually evolves faster than

360 the F genome in species with DUI, i.e. because of relaxed selective constraints (Stewart et al.,

361 1996; Zouros, 2000; Passamonti, Boore \& Scali, 2003). The other hypotheses that have been

362 proposed to explain the higher rate of evolution of the $\mathrm{M}$ genome include (i) a higher number of

363 male germ line mitotic divisions preceding gametogenesis compared to the female germ line

364 (Selwood, 1968; Zwaan \& Mathieu, 1992; Stewart et al., 1996), (ii) a greater degree of oxidative

365 damage in metabolically active sperm relative to eggs (Stewart et al., 1996; Zouros, 2013) and/or

366 (iii) a smaller effective population size of male mitochondria compared to female mitochondria

367 (Stewart et al., 1996; Zouros, 2013).

As for other recent morphological and molecular studies based on mtDNA and nuclear

369 sequences (Giribet \& Wheeler, 2002; Giribet \& Distel, 2003; Bieler \& Mikkelsen, 2006; Plazzi

\& Passamonti, 2010; Plazzi et al., 2011; Breton et al., unpublished), our results support a more

371 derived Nuculanoida clustering with Pteriomorphia instead of a basal position of Nuculanoida +

372 Opponobranchia (=Protobranchia). Therefore, the question about the origin of DUI in the branch

373 leading to the Autolamellibranchia about 460 Mya (Little \& Vrijenhoek, 2003) or much earlier,

374 perhaps in the early Cambrian (Boyle \& Etter, 2013), still remains open. The taxonomic position

375 of $Y$. hyperborea and other members of the order Nuculanoida should be tested using an

376 expanded data set. A robust bivalve phylogeny, as well as a much more accurate understanding 
377 of the taxonomic distribution of DUI, is needed to allow a rigorous evaluation of a single vs.

378 multiple origins of DUI.

379 Figures 1 to 4 demonstrate one split between $\mathrm{M}$ and $\mathrm{F}$ types at the base of the Unionoida,

380 and one split for each species exhibiting a taxon-specific pattern. Taken at face value, this pattern

381 implies a large number of independent origins of DUI. Given the rare molecular and

382 developmental complexity associated to the DUI system, this hypothesis seems unlikely but

383 cannot be completely rejected yet (Zouros, 2013). The opposite hypothesis of a single origin of

384 DUI can only be true if associated with masculinization events along each branch of the

385 phylogenetic tree of the Bivalvia where F and M types are each other's closest relatives. Such

386 masculinization events have already been clearly demonstrated in Mytilus (reviewed in Stewart

387 et al., 2009; Zouros, 2013), and evidence suggests that mitochondrial recombination and

388 acquisition of key elements of the evolutionarily older $\mathrm{M}$ mt genome (i.e., sperm transmission

389 elements) are necessary for a F genome to be transmitted via sperm (e.g., Stewart et al., 2009;

390 Zouros, 2013; Kyriakou et al., 2015). Because masculinization events restore nucleotide

391 divergence between $\mathrm{F}$ and $\mathrm{M}$ mtDNAs to zero for most of the genes in each of the sex-associated

392 genome (except for key sperm transmission elements), this phenomenon could explain the F/M

393 phylogenetic patterns of mytiloids, nuculanoids and veneroids. As a consequence of the many

394 similarities found among the distantly-related DUI species (e.g., sex ratio bias, mitochondria's

395 behavior in the newly formed zygotes, rates of evolution of the two genomes), and because of the

396 complexity of the DUI system, one could thus favor the hypothesis of a single origin of DUI with

397 repeated masculinization events. However, recent in silico analyses of the novel mtDNA-

398 encoded protein-coding genes, i.e. ORFan genes with no known homologous, which have been

399 found in species with DUI support either a viral or a mitochondrial origin for these genes that are 
400 most probably involved in the DUI mechanism (Milani et al., 2013; Milani et al., 2014; Mitchell

401 et al., 2016; Milani et al., 2016). These results suggest the possibility of DUI systems with

402 elements of different sources/origins and different mechanisms of action in the distantly-related

403 DUI taxa (i.e. DUI could be achieved by different modifications of strictly maternal inheritance

404 of mitochondria), and this scenario would best fit multiple origins of DUI and the necessary

405 factors.

406 To conclude, our study presents evidence for the existence of DUI in the nuculanoid

407 species Yoldia hyperborea and the veneroid species Scrobicularia plana. Because the taxonomic

408 position of $Y$. hyperborea and its order Nuculanoida has been debated over the years and still

409 remain uncertain, the question about the origin of DUI during the Cambrian or before is still

410 unresolved. A much more accurate understanding of the taxonomic distribution of DUI across

411 the Bivalvia appears to be a priority to help confirming the single or multiple origins of this

412 unusual system of mitochondrial heredity. Testing for its presence in all bivalve superfamilies,

413 especially the one not studied yet (e.g., Solemyoidea, Lucinoidea, Carditoidea), is the only way

414 to make a definitive statement.

415

416 Acknowledgements

417 We would like to thank Cindy Grant and Françoise Denis for providing us the samples, El-

418 Amine Mimouni for his assistance with the phylogenetic analyses, and two anonymous

419 reviewers for insightful criticisms and suggestions.

420

421 References

422 Akaike H. 1973. Information theory and an extension of the maximum likelihood principle. In: 
423

424

425

426

427

428

429

430

431

432

433

434

435

436

437

438

439

440

441

442

443

444

445

Petrov BN, Caski F, ed. Proceeding of the Second International Symposium on Information Theory. Budapest: Akademiai Kiado, 267-281.

Alves FA, Beasley CR, Hoeh WR, da Rocha RM, de Simone LR, Tagliaro CH. 2012.

Detection of mitochondrial DNA heteroplasmy suggests a doubly uniparental inheritance pattern in the mussel Mytella charruana. Revista Brasileira de Biociências 10(2):176-185.

Beagley CT, Taylor KA, Wolstenholme DR. 1997. Gender-associated diverse

mitochondrial DNA molecules of the mussel Mytilus californianus. Current Genetics 31(4):318-324. DOI 10.1007/s002940050211.

Bieler R, Mikkelsen PM. 2006. Bivalvia - a look at the branches. Zoological Journal of the Linnean Society 148:223-235. DOI 10.1111/j.1096-3642.2006.00255.x.

BivAToL: Assembling the Bivalve Tree of Life. Available at http://www.bivatol.org/index.php/the-project (accessed $21^{\text {st }}$ July 2016)

Boyle EE, Etter RJ. 2013. Heteroplasmy in a deep-sea protobranch bivalve suggests an ancient origin of doubly uniparental inheritance of mitochondria in Bivalvia. Marine Biology 160(2):413-422. DOI 10.1007/s00227-012-2099-y.

Breton S, Burger G, Stewart DT, Blier PU. 2006. Comparative analysis of gender-associated, complete mitochondrial genomes in marine mussels (Mytilus spp.). Genetics 172(2):1107-1119. DOI 10.1534/genetics.105.047159.

Breton S, Doucet-Beaupré H, Stewart DT, Hoeh WR, Blier PU. 2007. The unusual system of doubly uniparental inheritance of mtDNA: isn’t one enough? Trends in Genetics 23(9):465-474. DOI 10.1016/j.tig.2007.05.011.

Breton S, Stewart DT, Shepardson S, Trdan RJ, Bogan AE, Chapman EG, Ruminas AJ, Piontkivska H, Hoeh WR. 2011a. Novel Protein genes in Animal mtDNA: A New Sex 
446

447

448

449

450

451

452

453

454

455

456

457

458

459

460

461

462

463

464

465

466

467

Determination System in Freshwater Mussels (Bivalvia: Unionoida). Molecular Biology and Evolution 28(5):1645-1659. DOI 10.1093/molbev/msq345.

Breton S, Ghiselli F, Passamonti M, Milani L, Stewart DT, Hoeh WR. 2011b. Evidence for a fourteenth mtDNA-encoded protein in the female-transmitted mtDNA of marine mussels (Bivalvia: Mytilidae). PLoS One 6(4):e19365. DOI 10.1371/journal.pone.0019365.

\section{Breton S, Milani L, Ghiselli F, Guerra D, Stewart DT, Passamonti M. 2014. A} resourceful genome: updating the functional repertoire and evolutionary role of animal mitochondrial DNAs. Trends in Genetics 30(12):555-564. DOI 10.1016/j.tig.2014.09.002.

Breton S, Stewart DT. 2015. Atypical mitochondrial inheritance patterns in eukaryotes. Genome 58(10):423-431. DOI 10.1139/gen-2015-0090.

Cao L, Kenchington E, Zouros E. 2004. Differential segregation patterns of sperm mitochondria in embryos of the blue mussel (Mytilus edulis). Genetics 166(2):883-894. DOI 10.1534/genetics.166.2.883.

Cao X, Wang G, Li J. 2012. Detection of the doubly uniparental inheritance in Chinese freshwater mussels through testing the gender-related cytochrome oxidase II gene. Unpublished.

\section{Chakrabarti R, Walker JM, Stewart DT, Trdan RJ, Vijayaraghavan S, Curole JP, Hoeh} WR. 2006. Presence of a unique male-specific extension of $\mathrm{C}$-terminus to the cytochrome c oxidase subunit II protein coded by the male-transmitted mitochondrial genome of Venustaconcha ellipsiformis (Bivalvia: Unionoidea). FEBS Letters 580(3):862-866. DOI 10.1016/j.febslet.2005.12.104. 
468

469

470

471

472

473

474

475

476

477

478

479

480

481

482

Chakrabarti R, Walker JM, Chapman EG, Shepardson SP, Trdan RJ, Curole JP, Watters GT, Stewart OT, Vijayaraghavan S, Hoeh WR. 2007. Reproductive function for a cterminus extended, male-transmitted cytochrome c oxidase subunit Il protein expressed in both spermatozoa and eggs. FEBS Letters 581(27):5213-5219.

DOI 10.1016/j.febslet.2007.10.006.

Chapman EG, Piontkivska H, Walker JM, Stewart DT, Curole JP, Hoeh WR. 2008.

Extreme primary and secondary protein structure variability in the chimeric maletransmitted cytochrome c oxidase subunit II protein in freshwater mussels: Evidence for an elevated amino acid substitution rate in the face of domain-specific purifying selection. BMC Evolutionary Biology 8:165. DOI 10.1186/1471-2148-8-165.

Chesman BS, Langston WJ. 2006. Intersex in the clam Scrobicularia plana: a sign of endocrine disruption in estuaries? Biology Letters 2(3):420-422. DOI 10.1098/rsbl.2006.0482.

Ciocan CM, Cubero-Leon E, Peck MR, Langston WJ, Pope N, Minier C, Rotchell JM. 2012. Intersex in Scrobicularia plana: Transcriptomic Analysis Reveals Novel Genes Involved in Endocrine Disruption. Environmental Science \& Technology 46(23):1293612942. DOI 10.1021/es302948g.

Cogswell AT, Kenchington EL, Zouros E. 2006. Segregation of sperm mitochondria in two and four-cell embryos of the blue mussel Mytilus edulis: implications for the mechanism of doubly uniparental inheritance of mitochondrial DNA. Genome 49(7):799-807. DOI 10.1139/g06-036.

Curole JP, Kocher TD. 2002. Ancient sex-specific extension of the cytochrome c oxidase II gene in bivalves and the fidelity of doubly-uniparental inheritance. 
491

492

493

494

495

496

497

498

499

500

501

502

503

504

505

506

507

508

509

510

511

512

513

Molecular Biology and Evolution 19(8):1323-1328. DOI

10.1093/oxfordjournals.molbev.a004193.

Curole JP, Kocher TD. 2005. Evolution of a unique mitotype-specific protein-coding extension of the cytochrome c oxidase II gene in freshwater mussels (Bivalvia: Unionoida). Journal of Molecular Evolution 61(3):381-389. DOI 10.1007/s00239-004-0192-7.

Dégletagne C, Abele D, Held C. 2016. A distinct mitochondrial genome with DUI-like inheritance in the ocean quahog Arctica islandica. Molecular Biology and Evolution 33(2):375-383. DOI 10.1093/molbev/msv224.

\section{Doucet-Beaupré H, Breton S, Chapman EG, Blier PU, Bogan AE, Stewart DT, Hoeh WR.} 2010. Mitochondrial phylogenomics of the Bivalvia (Mollusca): searching for the origin and mitogenomic correlates of doubly uniparental inheritance of mtDNA. BMC Evolutionary Biology 10:50. DOI 10.1186/1471-2148-10-50.

Felsenstein J. 1985. Phylogenies and the comparative method. American naturalist 125(1):1-15.

Folmer O, Black M, Hoeh WR, Lutz R, Vrijenhoek RC. 1994. DNA primers for amplification of mitochondrial cytochrome c oxidase subunit I from diverse metazoan invertebrates. Molecular Marine Biology and Biotechnology 3(5):294-299.

Gelman A, Rubin DB. 1992. Inference from iterative simulation using multiple sequences. Statistical Science 7(4):457-472.

Giribet G, Wheeler W. 2002. On bivalve phylogeny: a high-level analysis of the Bivalvia (Mollusca) based on combined morphology and DNA sequence data. Invertebrate Biology 121(4):271-324. DOI 10.1111/j.1744-7410.2002.tb00132.x.

Giribet G, Distel DL. 2003. Bivalve phylogeny and molecular data. In: Lydeard C, Lindberg DR, Ed. Molecular Systematics and Phylogeography of Mollusks. Washington DC: 
514 Smithsonian Books, 45-90.

515 Giribet G. 2008. Bivalvia, in: Phylogeny and Evolution of the Mollusca. University of $516 \quad$ California Press.

517 González VL, Andrade SCS, Bieler R, Collins TM, Dunn CW, Mikkelsen PM, Taylor JD,

518 Giribet G. 2015. A phylogenetic backbone for Bivalvia: An RNA seq approach.

519 Proceedings of the Royal Society B: Biological Sciences 282(1801):20142332. DOI

$520 \quad 10.1098 /$ rspb.2014.2332.

521 Gusman A, Azuelos C, Breton S. In press. No evidence of sex-linked heteroplasmy and doubly

522 uniparental inheritance of mtDNA in five gastropod species. Journal of Molluscan Studies.

523 Hoeh WR, Blakley KH, Brown WM. 1991. Heteroplasmy suggests limited biparental

524 inheritance of Mytilus mitochondrial DNA. Science 251(5000):1488-1490. DOI

$525 \quad 10.1126 /$ science. 1672472.

526 Hoeh WR, Stewart DT, Sutherland BW, Zouros E. 1996. Multiple origins of gender-

527 associated mitochondrial DNA lineages in bivalves (Mollusca: Bivalvia). Evolution $528 \quad 50(6): 2276-2286$. DOI $10.2307 / 2410697$.

529 Hoeh WR, Stewart DT, Guttman SI. 2002. High fidelity of mitochondrial genome 530 transmission under the doubly uniparental mode of inheritance in freshwater mussels 531 (Bivalvia: Unionoidea). Evolution 56(11):2252-2261. DOI 10.1111/j.0014$532 \quad 3820.2002 . t b 00149 . x$

533 Huang XC, Rong J, Liu Y, Zhang MH, Wan Y, Ouyang S, Zhou CH, Wu XP. 2013. The 534 complete maternally and paternally inherited mitochondrial genomes of the endangered 535 freshwater mussel Solenaia carinatus (Bivalvia: Unionidae) and implications for $536 \quad$ Unionidae taxonomy. PLoS One 8(12):e84352. DOI 10.1371/journal.pone.0084352. 
537 Huelsenbeck JP, Ronquist F. 2001. MRBAYES: Bayesian inference of phylogeny.

538 Bioinformatics 17(8):754-755. DOI 10.1093/bioinformatics/17.8.754

539 Huelsenbeck JP, Ronquist F. 2005. Bayesian analysis of molecular evolution using

540 MrBayes. In: Nielsen R, ed. Statistical Methods in Molecular Evolution. New-York:

541 Springer-Verlag, 183-226. DOI 10.1007/0-387-27733-1_7.

542 Kenchington E, MacDonald B, Cao L, Tsagkarakis D, Zouros E. 2002. Genetics of mother-

543 dependent sex ratio in blue mussels (Mytilus spp.) and implications for doubly uniparental

544 inheritance of mitochondrial DNA. Genetics 161:1579-1588.

545 Kenchington E, Hamilton L, Cogswell A, Zouros E. 2009. Paternal mtDNA and maleness are

546 co-inherited but not causally linked in mytilid mussels. PLoS ONE 4(4):e6976. DOI

$547 \quad$ 10.1371/journal.pone.0006976.

548 Kyriakou E, Kravariti L, Vasilopoulos T, Zouros E, Rodakis GC. 2015. A protein binding

549 site in the M mitochondrial genome of Mytilus galloprovincialis may be responsible for its

550 paternal transmission. Gene 562(1):83-94. DOI 10.1016/j.gene.2015.02.047.

551 Lanfear R, Calcott B, Ho SYW, Guindon S. 2012. Partitionfinder: combined selection of

552 partitioning schemes and substitution models for phylogenetic analyses. Molecular Biology

553 and Evolution 29(6):1695-1701. DOI 10.1093/molbev/mss020.

554 Lee T, Foighil DO. 2004. Hidden Floridian biodiversity: mitochondrial and nuclear gene trees

555 reveal four cryptic species within the scorched mussel, Brachidontes exustus, species

556 complex. Molecular Ecology 13(11):3527-3542. DOI 10.1111/j.1365-294X.2004.02337.x.

557 Lee JS, Lee YG, Kang SW, Park JS, Lee DG, Jeon MA, Ju SM. 2010. Intersexuality of

558 Crassostrea gigas and Ruditapes philippinarum in Southern Coastal Waters of Korea.

559 Environmental Health and Toxicology 25(4):287-294. 
560 Little CTS, Vrijenhoek RC. 2003. Are hydrothermal vent animals living fossils? Trends in $561 \quad$ Ecology and Evolution 18(11):582-588. DOI 1016/j.tree.2003.08.009.

562 Liu HP, Mitton JB, Wu SK. 1996. Paternal mitochondrial DNA differentiation far exceeds 563 maternal DNA and allozyme differentiation in the freshwater mussel Anodonta grandis 564 grandis. Evolution 50(2):952-957. DOI 10.2307/2410870.

565 Machordom A, Araujo R, Toledo C, Zouros E, Ladoukakis ED. 2015. Female-dependant 566 transmission of paternal mtDNA is a shared feature of bivalve species with doubly uniparental inheritance (DUI) of mitochondrial DNA. Journal of Zoological Systematics and Evolutionary Research 53(3):200-204. DOI 10.1111/jzs.12096.

Milani L, Ghiselli F, Passamonti M. 2012. Sex-linked mitochondrial behavior during early embryo development in Ruditapes philippinarum (Bivalvia: Veneridae) a species with the Doubly Uniparental Inheritance (DUI) of mitochondria. Journal of Experimental Zoology Part B: Molecular and Developmental evolution 318(3):182-189. DOI

573 10.1002/jez.b.22004.

\section{4}

575

576

577

578

579

580

581

582

Milani L, Ghiselli F, Guerra D, Breton S, Passamonti M. 2013. A comparative analysis of mitochondrial ORFans: new clues on their origin and role in species with doubly uniparental inheritance of mitochondria. Genome Biology and Evolution 5(7):1408-1434 DOI 10.1093/gbe/evt101.

Milani L, Ghiselli F, Maurizii MG, Nuzdhin SV, Passamonti M. 2014. Paternally transmitted mitochondria express a new gene of potential viral origin. Genome Biology and Evolution 6(2):391-405. DOI 10.1093/gbe/evu021.

Milani L, Ghiselli F, Passamonti M. 2016. Mitochondrial selfish elements and the evolution of biological novelties. Current Zoology DOI 10.1093/cz/zow044. 
583 Mitchell A, Guerra D, Stewart DT, Breton S. 2016. In silico analyses of mitochondrial

584 ORFans in freshwater mussels (Bivalvia: Unionoida) provide a framework for future 585 studies of their origin and function. BMC Genomics 17:597. DOI 10.1186/s12864-016586 2986-6.

587 Mock KE, Brim-Box JC, Miller MP, Downing ME, Hoeh WR. 2004. Genetic diversity and 588 divergence among freshwater mussel (Anodonta) populations in the Bonneville Basin of 589 Utah. Molecular Ecology 13(5):1085-1098. DOI 10.1111/j.1365-294X.2004.02143.x.

590 Morariu VI, Srinivasan BV, Raykar VC, Duraiswami R, Davis LS. 2008. Automatic online 591 tuning for fast Gaussian summation. Advances in Neural Information Processing Systems 592 (NIPS), 1113-1120.

593 Obata M, Komaru A. 2005. Specific location of sperm mitochondria in mussel Mytilus 594 595 galloprovincialis zygotes stained by mitotracker. Development, Growth \& Differentiation 47(4):255-263. DOI 10.1111/j.1440-169X.2005.00801.x.

Ortiz-Zarragoitia M. Cajaraville MP. 2010. Intersex and oocyte atresia in a mussel population 597 from the Biosphere's Reserve of Urdaibai (Bay of Biscay). Ecotoxicology and Environmental Safety 73(5):693-701. DOI 10.1016/j.ecoenv.2010.04.002.

Palumbi S, Martin A, Romano S, Mcmillan WO, Stice L, Grabowski G. 1991. The Simple Fool's Guide to PCR, version 2.0. Honolulu: Privately published. uniparental inheritance of mtDNA in the apple snail Pomacea diffusa. Mitochondrial DNA 28:1-3. DOI 10.3109/19401736.2014.989521. 
604 Passamonti M, Scali V. 2001. Gender-associated mitochondrial DNA heteroplasmy in the 605 venerid clam Tapes philippinarum (Mollusca Bivalvia). Current Genetics 39(2):117-124.

606 DOI 10.1007/s002940100188.

607 Passamonti M, Boore JL, Scali V. 2003. Molecular evolution and recombination in gender608 associated mitochondrial DNAs of the manila clam Tapes philippinarum. Genetics

609 164(2):603-611.

Passamonti M. 2007. An unusual case of gender-associated mitochondrial DNA heteroplasmy: the mytilid Musculista senhousia (Mollusca Bivalvia). BMC Evolutionary Biology 7(Suppl 2):S7. DOI 10.1186/1471-2148-7-S2-S7.

Passamonti M, Ghiselli F. 2009. Doubly Uniparental Inheritance: two mitochondrial genomes, one precious model for organelle DNA inheritance and evolution. DNA and Cell evolution as revealed by mitochondrial genes. Molecular Phylogenetics and Evolution 57(2):641-657. DOI 10.1016/j.ympev.2010.08.032.

619

620

621

622

623

624

625 Biology 28(2):79-89. DOI 10.1089/dna.2008.0807.

Plazzi F, Passamonti M. 2010. Towards a molecular phylogeny of Mollusks: Bivalves early

Plazzi F, Ceregato A, Taviani M, Passamonti M. 2011. A Molecular Phylogeny of Bivalves, Ancient Radiations and Divergences as revealed by Mitochondrial Genes. PLoS one 6(11):1-16. DOI 10.1371/journal.pone.0027147.

Plazzi F, Cassano A, Passamonti M. 2015. The Quest for Doubly Uniparental Inheritance in heterodont bivalves and its detection in Meretrix lamarckii (Veneridae: Meretricinae). Journal of Zoological Systematics and Evolutionary Research 53(1):87-94. DOI 10.1111/jzs.12078. 
626 Plazzi F. 2015. The detection of sex-linked heteroplasmy in Pseudocardium sachalinense 627 (Bivalvia: Mactridae) and its implications for the distribution of doubly uniparental 628 inheritance of mitochondrial DNA. Journal of Zoological Systematics and Evolutionary $629 \quad$ Research 53(3):205-210. DOI 10.1111/jzs.12097.

630 Quesada H, Skibinski DAG, Skibinski DOF. 1996. Sex-biased heteroplasmy and

631

632

633

634

635

636

637

638

639

640

641

642

643

644

645

646

647 mitochondrial DNA inheritance in the mussel Mytilus galloprovincialis Lmk. Current Genetics 29(5):423-426. DOI 10.1007/BF02221509.

Sharma PP, González VL, Kawauchi GY, Andrade SCS, Guzmán A, Collins TM, Glover EA, Harper EM, Healy JM, Mikkelsen PM, Taylor JD, Bieler R, Giribet G. 2012. Phylogenetic analysis of four nuclear protein-encoding genes largely corroborates the traditional classification of Bivalvia (Mollusca). Molecular Phylogenetics and Evolution 65(1):64-74. DOI 10.1016/j.ympev.2012.05.025.

Soroka M. 2005. Genetic variability among freshwater mussel Anodonta woodiana (Lea, 1834) (Bivalvia: Unionidae) populations recently introduced in Poland. Zoological Science 22(10):1137-1144. DOI 10.2108/zsj.22.1137.

Soroka M. 2008. Doubly uniparental inheritance of mitochondrial DNA in the freshwater bivalve Anodonta woodiana (Bivalvia: Unionidae). Folia Biologica 56(1-2):91-95. DOI 10.3409/fb56_1-2.91-95.

Soroka M. 2010. Characteristics of mitochondrial DNA of unionid bivalves (Mollusca: Bivalvia: Unionidae). I. Detection and characteristics of doubly uniparental inheritance (DUI) of unionid mitochondrial DNA. Folia Malacologia 18(4):147-188. DOI 10.2478/v10125-010-0015-y. 
648 Skibinski DOF, Gallagher C, Beynon CM. 1994. Sex-limited mitochondrial DNA

649 transmission in the marine mussel Mytilus edulis. Genetics 138(3):801-809.

650 Ronquist F, Teslenko M, Van der Mark P, Ayres DL, Darling A, Höhna S, Larget B, Liu L,

651 Suchard MA, Huelsenbeck JP. 2012. MrBayes 3.2: Efficient bayesian phylogenetic

652 inference and model choice across a large model space. Systematic Biology 61(3):539-

653 542. DOI 10.1093/sysbio/sys029.

654 Schwarz G. 1978. Estimating the dimension of a model. Annals of Statistics 6(2):461-464.

655 Selwood L. 1968. Interrelationships between the developing oocytes and ovarian tissues in the

656 chiton Sypharochiton septentriones (Ashby) (Mollusca, Polyplacophora). Journal of

657 Morphology 125(1):71-104. DOI 10.1002/jmor.1051250105.

658

659

660

661

662

663

664

665

666

667

668

669
Smith SA, Wilson NG, Goetz FE, Feeher C, Andrade SCS, Rouse GW, Giribet G, Dunn CW. 2011. Resolving the evolutionary relationships of mollusks with phylogenomic tools. Nature 480(7377):364-367. DOI 10.1038/nature10526.

Stamatakis A. 2014. RAxML Version 8: A tool for Phylogenetic Analysis and Post-Analysis of Large Phylogenies. Bioinformatics 30(9):1312-1313. DOI

10.1093/bioinformatics/btu033.

Stewart DT, Kenchington ER, Singh RK, Zouros E. 1996. Degree of selective constraint as an explanation of the different rates of evolution of gender-specific mitochondrial DNA lineages in the mussel Mytilus. Genetics 143(3):1349-1357.

Stewart DT, Breton S, Blier PU, Hoeh WR. 2009. Masculinization events and doubly uniparental inheritance of mitochondrial DNA: A model for understanding the evolutionary dynamics of gender-asssociated mtDNA in mussels. In: Pontarotti P, ed. 
670

671

672

673

674

675

676

677

678

679

680

681

682

683

684

685

686

687

688

689

690

691

692

Evolutionary Biology from Concept to Application II. Berlin: Springer-Verlag, 163-173. DOI 10.1007/978-3-642-00952-5_9.

Stewart DT, Hoeh WR, Bauer G, Breton S. 2013. Mitochondrial Genes, Sex Determination and Hermaphroditism in Freshwater Mussels (Bivalvia : Unionoida). In: Pontarotti P, ed. Evolutionary Biology: Exobiology and Evolutionary Mechanisms. Berlin: SpringerVerlag, 245-255. DOI 10.1007/978-3-642-38212-3_16.

Sutherland B, Stewart D, Kenchington ER, Zouros E. 1998. The fate of paternal mitochondrial DNA in developing female mussels, Mytilus edulis: Implications for the mechanism of doubly uniparental inheritance of mitochondrial DNA. Genetics 148(1):341-347.

Swofford DL. 2001. PAUP*: Phylogenetic Analysis Using Parsimony (*and other methods). Sunderland: Sinauer Associates.

Tamura K, Stecher G, Peterson D, Filipski A, Kumar S. 2013. MEGA6: Molecular Evolutionary Genetics Analysis version 6.0. Molecular Biology and Evolution 30(12):2725-2729. DOI 10.1093/molbev/mst197.

Tavaré S. 1986. Some Probabilistic and Statistical Problems in the Analysis of DNA Sequences. Lectures on Mathematics in the Life Sciences 17:57-86.

Terranova MS, Lo Brutto S, Arculeo M, Mitton JB. 2007. A mitochondrial phylogeography of Brachidontes variabilis (Bivalvia, Mytilidae) reveals three cryptic species. Journal of Zoological Systematics and Evolutionary Research 45(4):289-298. DOI 10.1111/j.14390469.2007.00421.x.

Theologidis I, Fodelianakis S, Gaspar MB, Zouros E. 2008. Doubly Uniparental Inheritance (DUI) of Mitochondria DNA in Donax trunculus (Bivalvia: Donacidae) and the Problem 
693

694

695

696

697

698

699

700

701

702

703

704

705

706

707

708

709

710

711

712

713

714

of it's Sporadic Detection in Bivalvia. Evolution 62(4):959-970. DOI 10.1111/j.15585646.2008.00329.x.

Vargas J, Pérez M, Toro J, Astorga MP. 2015. Presence of two mitochondrial genomes in the mytilid Perumytilus purpuratus: Phylogenetic evidence for doubly uniparental inheritance. Genetics and Molecular Biology 38(2):173-181. DOI 10.1590/S1415-47573822201420140262.

Walker JM, Curole JP, Wade DE, Chapman EG, Bogan AE, Watters GT, Hoeh WR. 2006. Taxonomic distribution and phylogenetic utility of gender-associated mitochondrial genomes in the Unionoida: Bivalvia. Malacologia 48(1-2):265-282.

Wilson NG, Rouse GW, Giribet G. 2010. Assessing the molluscan hypothesis Serialia (Monoplacophora + Polyplacophora) using novel molecular data. Molecular Phylogenetics and Evolution 54(1):187-193. DOI 10.1016/j.ympev.2009.07.028.

Zouros E, Ball AO, Saavedra K, Freeman R. 1994a. An unusual type of mitochondrial DNA inheritance in the blue mussel Mytilus. Proceedings of the National Academy of Science 91(16):7463-7467.

Zouros E, Ball AO, Saavedra K, Freeman R. 1994b. Mitochondrial DNA inheritance. Nature 368(6474):818. DOI 10.1038/368818a0.

Zouros E. 2000. The exceptional mitochondrial DNA system of the mussel family Mytilidae. Genes \& Genetic Systems 75(6):313-318. DOI 10.1266/ggs.75.313.

Zouros E. 2013. Biparental inheritance through uniparental transmission: The Doubly Uniparental Inheritance (DUI) of mitochondrial DNA. Evolutionary Biology 40(1):1-31. DOI 10.1007/s11692-012-9195-2. 
715 Zwaan A, Mathieu M. 1992. The mussel Mytilus: Ecology, physiology, genetics and

716 aquaculture. In: Gosling EM, ed. Developments in aquaculture and fisheries science.

717 Amsterdam: Elsevier, 589. 


\section{Figure 1 (on next page)}

Bayesian inference majority-rule tree of bivalve cox1 partial sequence.

Figure 1. Bayesian inference majority-rule tree of bivalve cox1 partial sequence. Relationships based on an analysis using the GTR $+\mathrm{I}+\mathrm{G}$ model. Numbers at each node indicate nodal support. 


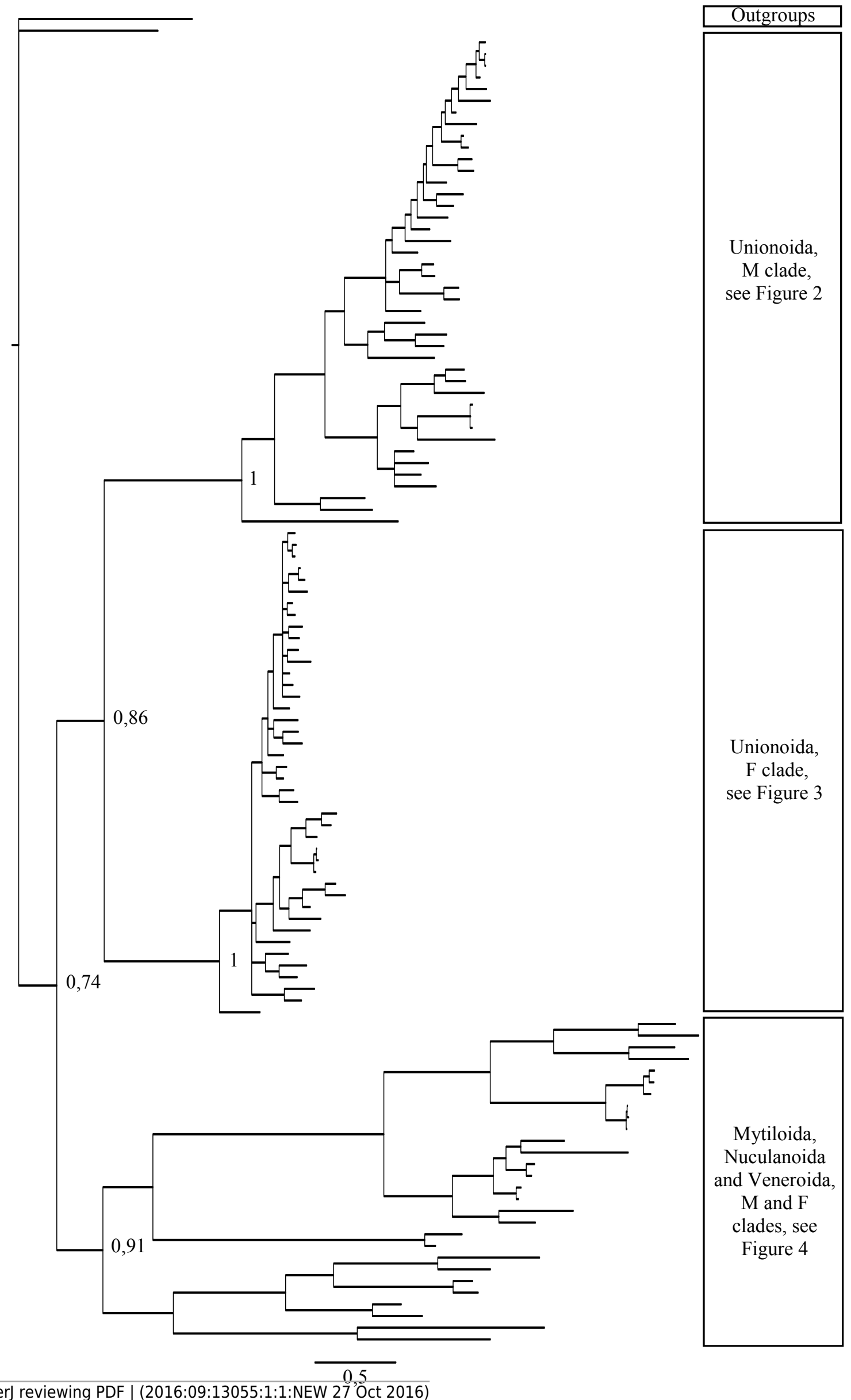




\section{Figure 2 (on next page)}

Bayesian inference majority-rule tree of bivalve cox1 partial sequence.

Figure 2. Bayesian inference majority-rule tree of bivalve cox1 partial sequence.

Relationships based on an analysis using the GTR $+\mathrm{I}+\mathrm{G}$ model. Unionoida M clade. Numbers at each node indicate nodal support. 


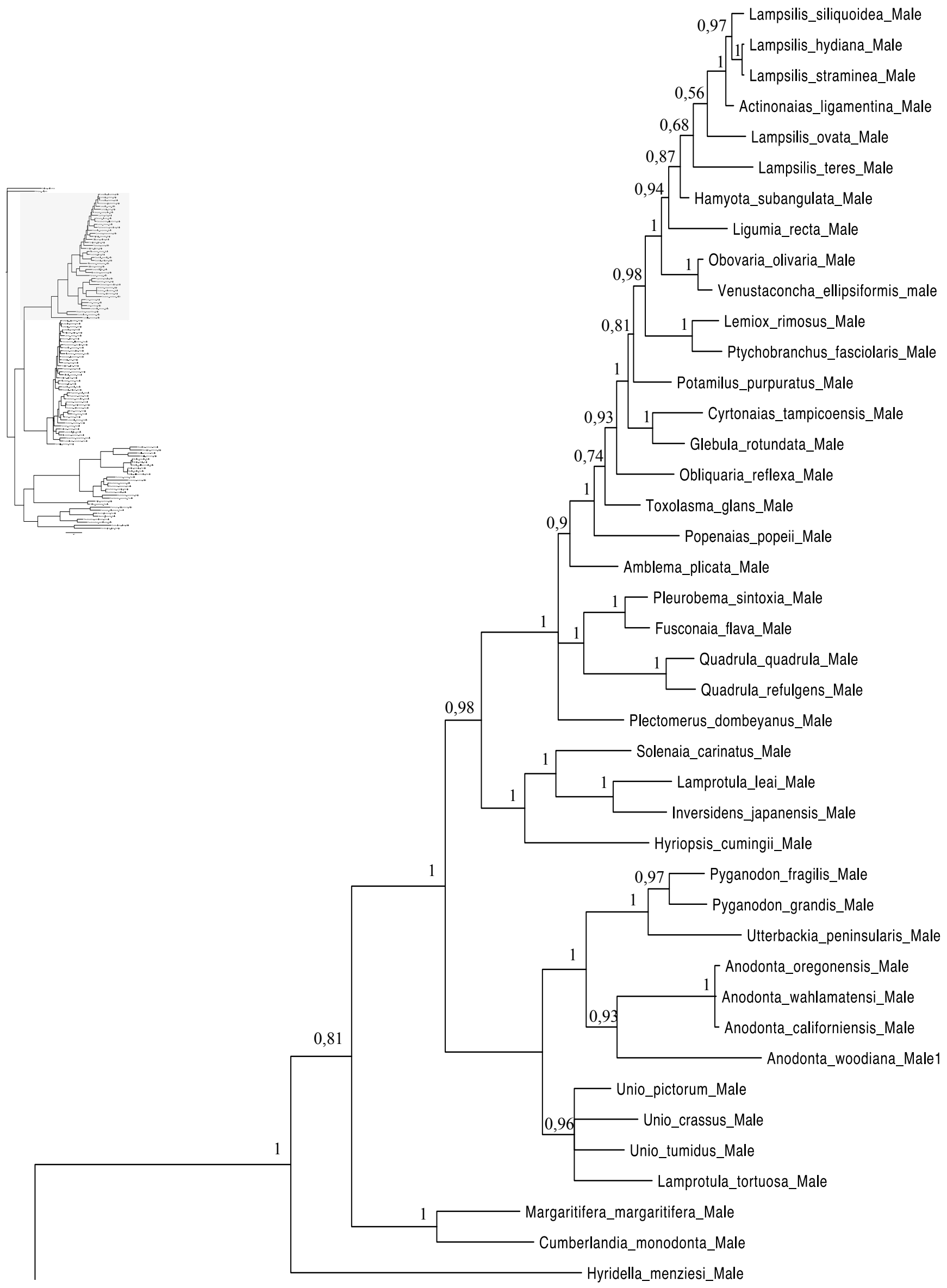




\section{Figure 3 (on next page)}

Bayesian inference majority-rule tree of bivalve cox1 partial sequence.

Figure 3. Bayesian inference majority-rule tree of bivalve cox1 partial sequence.

Relationships based on an analysis using the GTR $+\mathrm{I}+\mathrm{G}$ model. Unionoida F clade. Numbers at each node indicate nodal support. 

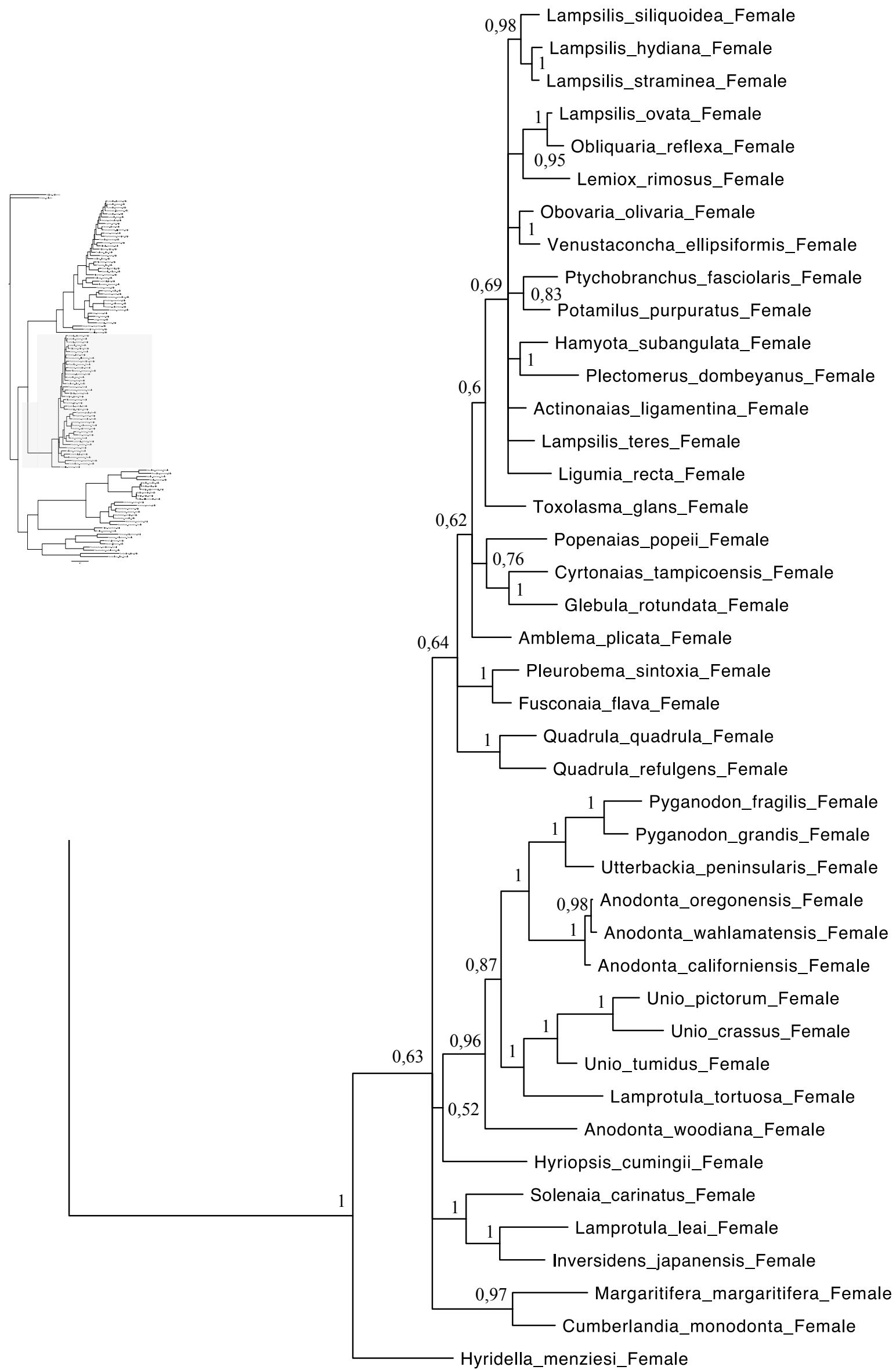


\section{Figure 4 (on next page)}

Bayesian inference majority-rule tree of bivalve cox1 partial sequence.

Figure 4. Bayesian inference majority-rule tree of bivalve cox1 partial sequence.

Relationships based on an analysis using the GTR $+\mathrm{I}+\mathrm{G}$ model. Mytiloida, Nuculanoida and Veneroida, M and F clades. Numbers at each node indicate nodal support. 


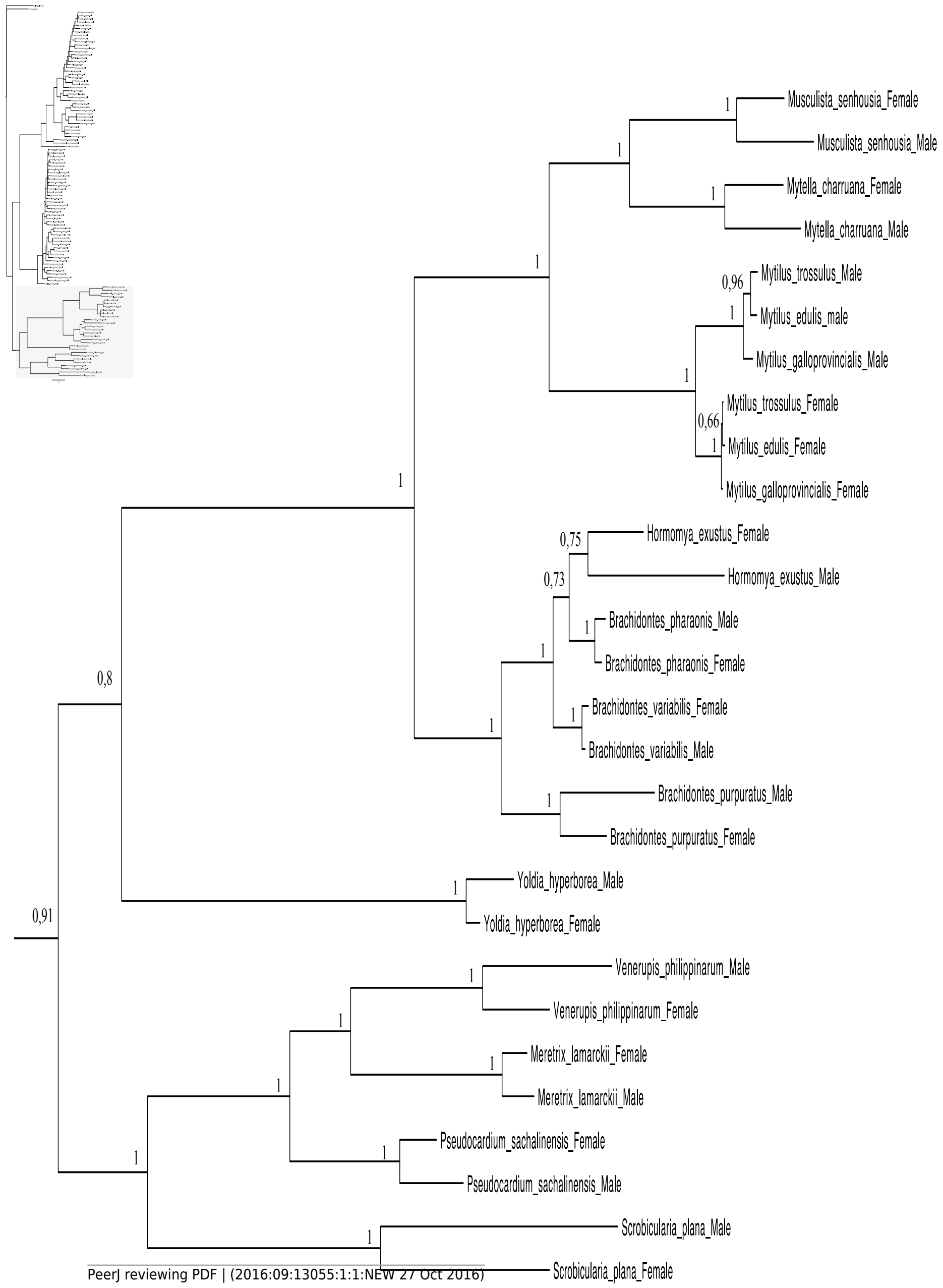




\section{Table $\mathbf{1}$ (on next page)}

Complete phylogenetic dataset used for phylogenetic reconstruction. GenBank accession numbers are listed in the last two columns. Sequences obtained for the present study are indicated in bold. 
1 Table 1. Complete phylogenetic dataset used for phylogenetic reconstruction. GenBank

2 accession numbers of sequences are listed in the last two columns. Sequences obtained for the

3 present study are indicated in bold.

\begin{tabular}{|c|c|c|c|}
\hline Species & Authority & M coxl & F coxl 1 \\
\hline Actinonaias ligamentina & (Lamarck, 1819) & AF406796 & AF231730 \\
\hline Amblema plicata & (Say, 1817) & EF033295 & EF033258 \\
\hline Anodonta californiensis & (Lea, 1852) & AY493507 & AY493462 \\
\hline Anodonta oregonensis & (Lea, 1838 & AY493504 & AY493480 \\
\hline Anodonta wahlamatensis & (Lea, 1838) & AY493493 & AY493467 \\
\hline Anodonta woodiana & (Lea, 1834) & EF440350 & HQ283346 \\
\hline Aplysia californica & (Cooper, 1863) & N/A & NC005827 \\
\hline Brachidontes exustus & (Linnaeus, 1758) & AY621946 & $\mathrm{NC} 024882$ \\
\hline Brachidontes pharaonis & (Fischer, 1870) & DQ836012 & DQ836013 \\
\hline Brachidontes variabilis & (Krauss 1848) & DQ836020 & DQ836019 \\
\hline Cumberlandia monodonta & (Say, 1829) & AY785397 & KF647529 \\
\hline Cyrtonaias tampicoensis & (Lea, 1838) & EF033299 & EF033259 \\
\hline Fusconaia flava & (Rafinesque, 1820) & EF033307 & EF033261 \\
\hline Glebula rotundata & (Lamarck, 1819) & EF033304 & EF033264 \\
\hline Graptacme eborea & (Conrad, 1846) & N/A & AY260825 \\
\hline Hamiota subangulata & (Lea, 1840) & EF033305 & EF033266 \\
\hline Echyridella menziesii & (Gray, 1843) & AF406802 & AF231747 \\
\hline Hyriopsis cumingii & (Lea, 1852) & KC150028 & HM347668 \\
\hline Unio japanensis & (Lea, 1859) & AB055624 & AB055625 \\
\hline Lamprotula leai & (Griffith, 1833) & KC847114 & JQ691662 \\
\hline Lamprotula tortuosa & (Lea, 1865) & KC441487 & KC109779 \\
\hline Lampsilis hydiana & (Lea, 1838) & EF033298 & EF033270 \\
\hline Lampsilis ovata & (Say, 1817) & EF033303 & EF033262 \\
\hline Lampsilis siliquoidea & (Barnes, 1823) & KC408795 & KC408768 \\
\hline Lampsilis straminea & (Conrad, 1834) & EF033297 & EF033271 \\
\hline Lampsilis teres & (Rafinesque, 1820) & AF406794 & KT285644 \\
\hline Lemiox rimosus & (Rafinesque, 1831) & EF033302 & EF033256 \\
\hline Ligumia recta & (Lamarck, 1819) & AF406795 & KC291717 \\
\hline Margaritifera margaritifera & (Linnaeus, 1758) & AY785399 & KC429108 \\
\hline Meretrix Lamarckii & (Deshayes, 1853) & KP244452 & KP244451 \\
\hline Musculista senhousia & (Benson, 1842) & AY570050 & AY570041 \\
\hline Mytella charuana & (Soot-Ryen, 1955) & JQ685159 & JQ685156 \\
\hline Mytilus californianus & (Conrad, 1837) & JX486123 & JX486124 \\
\hline Mytilus edulis & (Linnaeus, 1758) & AY484747 & HM489873 \\
\hline Mytilus galloprovincialis & (Lamarck, 1819) & AY363687 & AY497292 \\
\hline Mytilus trossulus & (Gould, 1850) & GQ438250 & AY823625 \\
\hline
\end{tabular}




\begin{tabular}{cccc} 
Obliquaria reflexa & (Rafinesque, 1820) & EF033292 & EF033254 \\
Obovaria olivaria & (Rafinesque, 1820) & EF033306 & EF033267 \\
Octopus vulgaris & (Cuvier, 1797) & N/A & AB191269 \\
Plectomerus dombeyanus & (Valenciennes, 1827) & EF033290 & EF033252 \\
Pleurobema sintoxia & (Rafinesque, 1820) & EF033291 & EF033253 \\
Popenaias popeii & (Lea, 1857) & EF033294 & EF033257 \\
Potamilus purpuratus & (Lamarck, 1819) & AF406797 & AF406804 \\
Pseudocardium sachalinense & (Schrenck, 1862) & KJ650517 & KJ650515 \\
Ptychobranchus fasciolaris & (Rafinesque, 1820) & EF033301 & EF033265 \\
Pyganodon fragilis & (Lamarck, 1819) & AF406800 & AF406805 \\
Pyganodon grandis & (Say, 1829) & FJ809755 & FJ809754 \\
Quadrula quadrula & (Rafinesque, 1820) & FJ809751 & FJ809750 \\
Quadrula refulgens & (Lea, 1868) & EF033309 & EF033269 \\
Scrobicularia plana & (Da Costa, 1778) & KX447424 & KX447420 \\
Solenaia carinatus & (Heude, 1877) & KC848655 & KC848654 \\
Toxolasma glans & (Lea, 1840) & EF033293 & EF033255 \\
Unio crassus & (Philipson, 1788) & EU548052| & KJ525915 \\
Unio pictorum & (Linnaeus, 1758) & EU548055 & HM014133 \\
Unio tumidus & (Philipson, 1788) & EU548054 & KC703957 \\
Utterbackia peninsularis & (Bogan \& Hoeh, 1995) & HM856635 & HM856636 \\
Venerupis philippinarum & (Adams, 1850) & AB065374 & AB065375 \\
Venustaconcha ellipsiformis & (Conrad, 1836) & FJ809752 & FJ809753 \\
Yoldia hyperborea & (Gould, 1841) & KX447428 & KX447425 \\
\hline & & &
\end{tabular}




\section{Table 2 (on next page)}

Number of sequences obtained for $S$. plana and $Y$. hyperborea. The number of haplotypes indicated regroups both $\mathrm{F}$ and $\mathrm{M}$ sequences. Genbank accession numbers are listed. Gi: Gills; Go: Gonads. 
1 Table 2. Number of sequences obtained for $S$. plana and $Y$. hyperborea. The number of 2 haplotypes indicated regroups both $\mathrm{F}$ and $\mathrm{M}$ sequences. Genbank accession numbers are listed. 3 Gi: Gills; Go: Gonads.

4

\begin{tabular}{ccccccc}
\hline & \multicolumn{2}{c}{ Cox1 Sequences } & & \multicolumn{2}{c}{ Cox1 Haplotypes } \\
\cline { 2 - 3 } Species & Female & Male & & Count & Genbank Ids \\
\cline { 2 - 3 } Scrobicularia plana & Gi/Go & Gi/Go & & & \\
Yoldia hyperborea & $7 / 3$ & $5 / 6$ & & 5 & KX447420-24 \\
\cline { 3 - 4 } & $7 / 4$ & $7 / 7$ & & 4 & KX447425-28 \\
\hline
\end{tabular}

5 


\section{Table 3(on next page)}

Nucleotide and amino acid Pairwise-distance for S. plana and Y. hyperborea cox 1 sequences.

Standard errors are given under p-distance values. Bold numbers indicate significant values for the presence of DUI. F: intrafemale divergence; $M$ : intramale divergence; F/M: divergence between males and females. 
1 Table 3. Nucleotide and amino acid Pairwise-distance for S. plana and Y. hyperborea cox1 2 sequences.

3

4

5

6

7

8

9

10

11

12

13

14

\begin{tabular}{|c|c|c|c|c|c|c|}
\hline \multirow{2}{*}{ Species } & \multicolumn{3}{|c|}{ coxl nucleotide sequences } & \multicolumn{3}{|c|}{ coxl amino acid sequences } \\
\hline & $\mathrm{F}$ & $\mathrm{M}$ & $\mathrm{F} / \mathrm{M}$ & $\mathrm{F}$ & M & $\mathrm{F} / \mathrm{M}$ \\
\hline \multirow[b]{2}{*}{ Scrobicularia plana } & 0.0067 & 0.0020 & 0.0965 & 0.0072 & 0.0000 & 0.0659 \\
\hline & \pm 0.0034 & \pm 0.0014 & \pm 0.0074 & \pm 0.0070 & \pm 0.0000 & \pm 0.0100 \\
\hline \multirow{2}{*}{ Yoldia hyperborea } & 0.0014 & 0.0000 & 0.0596 & 0.0000 & 0.0000 & 0.0454 \\
\hline & \pm 0.0008 & \pm 0.0000 & \pm 0.0079 & \pm 0.0000 & \pm 0.0000 & \pm 0.0124 \\
\hline
\end{tabular}

en under p-distance values. Bold numbers indicate significant values for the presence of DUI. F: intrafemale divergence; $\mathrm{M}$ : intramale divergence; F/M: divergence between males and females. 
Table 4(on next page)

List of species with DUI known to date. The taxonomic affiliation is made according to Giribet \& Wheeler (2002). Information about the presence of DUI was retrieved according to the references listed in the last column. 
1 Table 4. List of species with DUI known to date. The taxonomic affiliation is made according to 2 Giribet \& Wheeler (2002). Information about the presence of DUI was retrieved according to the 3 references listed in the last column.

4

\begin{tabular}{|c|c|c|}
\hline Superfamily/Family & Species & References \\
\hline \multirow[t]{31}{*}{ Unionoidea/Unionidae } & Actinonaias ligamentina & Hoeh, Stewart \& Guttman \\
\hline & Amblema plicata & Curole \& Kocher (2005) \\
\hline & Anodonta anatina & Soroka (2010) \\
\hline & Anodonta californensis & Mock et al. (2004) \\
\hline & Anodonta implicata & Curole \& Kocher (2002) \\
\hline & Anodonta oregonensis & Mock et al. (2004) \\
\hline & Anodonta wahlamatensis & Mock et al. (2004) \\
\hline & Anodonta woodiana & Soroka $(2005,2008)$ \\
\hline & Cyprogenia alberti & Walker et al. (2006) \\
\hline & Cyrtonaias tampicoensis & $\begin{array}{l}\text { Hoeh, Stewart \& Guttman } \\
\text { (2002) }\end{array}$ \\
\hline & Dromus dromas & Walker et al. (2006) \\
\hline & Ellipsaria lineolata & Walker et al. (2006) \\
\hline & Elliptio dilitata & Walker et al. (2006) \\
\hline & Epioblasma brevidens & Walker et al. (2006) \\
\hline & Glebula rotundata & Curole \& Kocher (2005) \\
\hline & Gonidea angulata & Walker et al. (2006) \\
\hline & Hamiota subangulata & Chapman et al. (2008) \\
\hline & Hyriopsis cumingii & Cao, Wang \& Li (2012) \\
\hline & Hyriopsis schlegelii & Lin et al. (2010) \\
\hline & Inversidens japanensis & $\begin{array}{l}\text { Doucet-Beaupré et al } \\
\text { (2010) }\end{array}$ \\
\hline & Lamprotula leai & Wang et al. (2013) \\
\hline & Lamprotula tortuosa & Cao, Wang \& Li (2012) \\
\hline & Potamilus purpuratus & $\begin{array}{l}\text { Hoeh, Stewart \& Guttman } \\
\text { (2002) }\end{array}$ \\
\hline & Lampsilis cardium & Walker et al. (2006) \\
\hline & Lampsilis hydiana & Walker et al. (2006) \\
\hline & Lampsilis ovata & Chapman et al. (2008) \\
\hline & Lampsilis powellii & Walker et al. (2006) \\
\hline & Lampsilis reeveiana & Walker et al. (2006) \\
\hline & Lampsilis siliquoidea & Walker et al. (2006) \\
\hline & Lampsilis streckeri & Walker et al. (2006) \\
\hline & Lampsilis straminea & Curole \& Kocher (2002) \\
\hline
\end{tabular}


Lampsilis teres

Lanceolaria grayana

Lasmigona complanata

Lasmigona costata

Lemiiox rimosus

Leptodea fragilis

Leptodea leptodon

Ligumia recta

Margaritifera marrianae

Medionidus conradicus

Obliquaria reflexa

Obovaria olivaria

Plectomerus dombeyanus

Pleurobema sintoxia

Popenaias popeii

Potamilus alatus

Potamilus capax

Potamilus ohiensis

Pseudodon

vondembuschianus

Ptychobranchus fasciolare

Pyganodon fragilis

Pyganodon grandis

Fusconaia flava

Quadrula quadrula

Quadrula refulgens

Solenaia carinatus

Strophitus undulatus

Toxolasma glans

Toxolasma lividus

Toxolasma minor

Toxolasma paulus

Truncilla truncate

Unio crassus

Unio delphinus

Unio pictorum

Unio tumidus

Utterbackia peggyae
Hoeh, Stewart \& Guttman (2002)

Okazaki, published only in database, (AB040829-30)

Stewart et al. (2013)

Stewart et al. (2013)

Chapman et al. (2008)

Walker et al. (2006)

Walker et al. (2006)

Hoeh, Stewart \& Guttman (2002)

Stewart et al. (2013)

Walker et al. (2006)

Chapman et al. (2008)

Walker et al. (2006)

Curole \& Kocher (2005)

Chapman et al. (2008)

Walker et al. (2006)

Walker et al. (2006)

Walker et al. (2006)

Walker et al. (2006)

Walker et al. (2006)

Walker et al. (2006)

Hoeh et al. (1996)

Liu, Mitton \& Wu (1996)

Hoeh et al. (1996)

Curole \& Kocher (2002)

Curole \& Kocher (2002)

Huang et al. (2013)

Stewart et al. (2013)

Stewart et al. (2013)

Stewart et al. (2013)

Stewart et al. (2013)

Stewart et al. (2013)

Walker et al. (2006)

Soroka (2010)

Machordom et al. (2015)

Soroka (2010)

Soroka (2010)

Breton et al. (2011a) 


\begin{tabular}{|c|c|c|}
\hline & Utterbackia peninsularis & Breton et al. (2011a) \\
\hline & Venustaconcha ellipsiformis & Chakrabarti et al. (2006) \\
\hline & Villosa lienosa & Curole \& Kocher (2005) \\
\hline & Villosa villosa & Walker et al. (2006) \\
\hline Unionoidea/Margaritiferidae & Cumberlandia monodonta & Breton et al. (2011a) \\
\hline & Dahurinaia dahurica & Walker et al. (2006) \\
\hline & Margaritifera hembeli & Curole \& Kocher (2005) \\
\hline & Margaritifera margaritifera & $\begin{array}{l}\text { Hoeh, Stewart \& Guttman } \\
\text { (2002) }\end{array}$ \\
\hline Hyrioidea/Hyriidae & Hyridella menziesi & $\begin{array}{l}\text { Hoeh, Stewart \& Guttman } \\
\text { (2002) }\end{array}$ \\
\hline Mytiloidea/Mytilidae & Brachidontes exustus & Lee and O'Foighil (2004) \\
\hline & Brachidontes pharaonis & Lee and O'Foighil (2004) \\
\hline & Brachidontes variabilis & Terranova et al. (2007) \\
\hline & Geukensia demissa & Hoeh et al. (1996) \\
\hline & Modiolus modiolus & $\begin{array}{l}\text { Robicheau et al. } \\
\text { unpublished data }\end{array}$ \\
\hline & Musculista senhousia & Passamonti (2007) \\
\hline & Mytella charuana & Alves et al. (2011) \\
\hline & Mytilus californianus & $\begin{array}{l}\text { Beagley, Taylor \& } \\
\text { Wolstenholme (1997) }\end{array}$ \\
\hline & Mytilus coruscus & Breton et al. (2011b) \\
\hline & Mytilus edulis & Zouros et al. (1994a) \\
\hline & Mytilus galloprovincialis & $\begin{array}{l}\text { Quesada, Skibinski \& } \\
\text { Skibinski (1996) }\end{array}$ \\
\hline & Mytilus trossulus & Zouros et al. (1994a) \\
\hline & Perumytilus purpuratus & Vargas et al. (2015) \\
\hline Arcticoidea/Arcticidae & Arctica islandica & $\begin{array}{l}\text { Dégletagne, Abele \& Held } \\
\text { (2016) }\end{array}$ \\
\hline Mactroidea/Mactridae & Pseudocardium sachalinense & Plazzi (2015) \\
\hline Solenoidea/Solenidae & Solen grandis & $\begin{array}{l}\text { Okazaki et al. Unpublished } \\
\text { (AB064984-5) }\end{array}$ \\
\hline Tellinoidea/Donacidae & Donax cuneatus & $\begin{array}{l}\text { Okazaki, published only in } \\
\text { database (AB040841-2) }\end{array}$ \\
\hline & Donax faba & $\begin{array}{l}\text { Okazaki, published only in } \\
\text { database (AB040843-4) }\end{array}$ \\
\hline & Donax trunculus & Theologidis et al. (2008) \\
\hline Tellinoidea/Semelidae & Scrobicularia plana & Present study \\
\hline Veneroidea/Veneridae & Cyclina sinensis & $\begin{array}{l}\text { Okazaki, published only in } \\
\text { database (AB040833-4) }\end{array}$ \\
\hline & Venerupis philippinarum & Passamonti \& Scali (2001) \\
\hline & Meretrix Lamarckii & Plazzi et al. (2014) \\
\hline Nuculanoidea/Nuculanidae & Ledella sublevis & Boyle \& Etter (2013) \\
\hline
\end{tabular}


Ledella ultima

Nuculanoidea/Yoldiidae

5

6

Present study 